www.jmscr.igmpublication.org

Impact Factor 5.84

Index Copernicus Value: 83.27

ISSN (e)-2347-176x ISSN (p) 2455-0450

crossref DOI: _https://dx.doi.org/10.18535/jmscr/v5i3.161

Journal Of Medical Science And Clinical Research

IGM Publication

An official Publication of IGM Publication

\title{
Cellulitis of Lower Limb- A Clinical and Microbiological Profile
}

\author{
Authors \\ Dr Minimol K. L. ${ }^{1}$, Dr Thomas P K ${ }^{2}$, Dr Balakrishnan G. ${ }^{3}$ \\ ${ }^{1}$ Associate Professor, General Surgery, ${ }^{2}$ Additional Professor, General Surgery \\ ${ }^{3}$ Junior Resident, General Surgery
}

\begin{abstract}
Background: Cellulitis is a common surgical condition defined as a spreading infection of the skin and subcutaneous tissue. The severity can vary from mild to life threatening condition. The risk factors of lower limb cellulitis, the common causative organisms, their sensitivity all remains controversial. This study aims at finding out the relative frequency of predisposing factors, the microbiological profile and sensitivity to aid in the better management of lower limb cellulitis.

Methods: This is a prospective study carried out in the Department of Surgery, Government Medical College Trivandrum. A total number of 60 patients were analysed.

Results: The commonest organism isolated was beta haemolytic streptococcus in the gram positive group, and klebsiella species in the gram negative group. Sensitivity to different antibiotics was analysed.

Conclusion: The predisposing factors identified for lower limb cellulitis include obesity, lymphedema, history of trauma and varicose veins. A larger study will be needed to assess the risk factors of lower extremity cellulitis.

Keywords: Cellulitis, lower extremity, sensitivity.
\end{abstract}

\section{Introduction}

Cellulitis is spreading inflammation of subcutaneous tissue ${ }^{(1)}$. Cellulitis can affect any part of the body and its severity varies from mild to fulminent disease ${ }^{(2,3)}$. Though there is no abscess formation, pus discharge or ulceration in cellulitis; these can coexist if there are any associated comorbidities like diabetes or vasculitis.

Cellulitis is not a surgical emergency, but it can be life threatening if left untreated or inadequately treated ${ }^{(4)}$. There are cases reported in literature where cellulitis starting as trivial lesion progresssing to life threatening condition. Mild cellulitis often goes unreported and can affect any individual irrespective of age, sex, race and ethnic group. However higher incidence is seen as age increases.
According to a retrospective study of international travelers by the geosentinal surveillance network, cellulitis was found to be more common in geriatric age group $^{(5)}$.

Statistics show that cellulitis account for about 3\% of emergency hospital registration ${ }^{(6)}$. Among them majority, approximately $80 \%$ is associated with comorbidities like diabetes, filariasis \& obesity ${ }^{(7)}$.

For the study to be genuine and credible, we need more prospective studies were cases are picked out accurately after ruling out DD's like lower limb eczema, oedema with blisters, DVT \& vasculitis. Majority of the previous studies were retrospective studies and their credibility is questionable. Despite the magnitude of problem, a good evidence based literature for management of cellulitis is 
lacking and there are no national guidelines. No randamised controlled trials take into consideration the effects of treating the predisposing factors on recurrence of cellulitis.

As cellulitis have variable etiology in different epidemiological settings; eliciting a good history including patients geographical locality, travel history, immune status, recent trauma, recent surgery, previous antibiotic treatment, life style \& exposure to animals and chemicals are key to developing an appropriate index of suspicion for specific etiological factors or agents.

A thorough physical examination not only of the affected part but also of the whole body and assessing the extension of inflammation into skin and underlying soft tissue is crucial in arriving at a correct diagnosis. Often, even this information will be insufficient in arriving at a clear diagnosis. In such cases an aspiration of tissue fluid or even a biopsy may aid in diagnosis. At times USG of the affected part may also be needed to assess the level of involvement and to rule out presence of gas or abscess $^{(8)}$. Early fasciotomy or debridement may also be needed for diagnosis as well as therapeutic purpose especially in those with immune-compromised condition and necrotizing infection ${ }^{(9-11)}$.

A recent Cochrane review concluded by Kilburn et al, show that it was not possible to define the best treatment for cellulitis in general, based on existing evidence $^{(12)}$.

All the above factors were considered, and a prospective study was conducted to determine the relative frequency of microbial isolates and its sensitivity pattern for better management of lower limb cellulitis and to prevent indiscriminate use of antibiotics.

\section{Materials and Methods}

This study was conducted in the Department of Surgery Medical College Trivandrum during 20142015. We recruited the patients after obtaining clearance from the institutional ethics committee. All patients admitted in the surgical wards of Medical College Trivandrum were eligible to be recruited in to the study. Patients above the age of
18 years old were only considered eligible for the study. All patients with suspected necrotizing fascitis were excluded from the study. Moreover, patients with ulcer foot were excluded. In addition, patients with associated cellulitis in another area apart from the lower limbs were not included in the study. We included all consecutive patients eligible for the study. All data were taken in a structured and standardized case report form. Data were taken by the investigator. Case report form included various variables we planned to study like demographic variables, details of admission and discharge, presenting complaints, clinical examination findings. We collected data about the location of the cellulitis, presence of lymphoedema, varicose veins, dermatological diseases and presence or absence of peripheral pulses. Biochemical parameters like fasting blood sugar, liver function tests, renal function test, blood routine, ultrasound, venous and arterial Doppler of lower limb. In addition, culture and sensitivity was done. We followed the declaration of Helsinki at the time of design and conduction of the study. All data was then entered into a computer database. Enough precaution was taken to safeguard the confidentiality of all patients at all phases of the study.

The diagnosis of the cellulitis was arrived at consensus of two independent consultants. Only those cases diagnosed as cellulitis by both consultants were considered for the study.

All measurements were taken in international units wherever appropriate. Biochemical investigations were carried out after calibration of the instruments.

All data were analyzed in SPSS and R statistical software. Continuous data were summarized in mean and standard deviation or median and interquartile distance. Categorical data were summarized with percentage or proportions. Comparison of means was tested with $t$ test and ANOVA for two and multiple groups respectively. p-value less than 0.05 were considered as significant. 


\section{Results}

A total of 60 patients were studied during the study period. Of these, majority were males $47(78.3 \%)$. Table 1 shows the baseline characteristics of the patients we studied. Most frequent medical condition associated with cellulitis in the lower limb was diabetes mellitus. In our study, 37 $(61.7 \%)$ patients had diabetes mellitus. Edema was present in $56(93.3 \%)$.

Table 1: Baseline characteristics

\begin{tabular}{|c|c|}
\hline Characters & Overall \\
\hline $\mathrm{n}$ & 60 \\
\hline Age (mean (sd)) & $54.42(11.86)$ \\
\hline Sex $=$ female/male $(\%)$ & $13 / 47(21.7 / 78.3)$ \\
\hline Duration (days). (median [IQR]) & $7.00[5.00,8.25]$ \\
\hline Trauma $=$ no/yes $(\%)$ & $47 / 13(78.3 / 21.7)$ \\
\hline \multicolumn{2}{|l|}{ History } \\
\hline Varicose veins $=$ no/yes $(\%)$ & $57 / 3(95.0 / 5.0)$ \\
\hline $\mathrm{POVD}=$ no/yes $(\%)$ & $51 / 9(85.0 / 15.0)$ \\
\hline Lymphedema $=$ no/yes $(\%)$ & $58 / 2(96.7 / 3.3)$ \\
\hline CLD $=$ no/yes $(\%)$ & $56 / 4(93.3 / 6.7)$ \\
\hline $\mathrm{DM}=$ no/yes $(\%)$ & $23 / 37(38.3 / 61.7)$ \\
\hline Skin disorder $=$ no/yes $(\%)$ & $56 / 4(93.3 / 6.7)$ \\
\hline Smoking $=$ no/yes $(\%)$ & $28 / 32(46.7 / 53.3)$ \\
\hline Alcoholism = no/yes $(\%)$ & $26 / 34(43.3 / 56.7)$ \\
\hline $\mathrm{HIV}=$ no/yes $(\%)$ & $57 / 3(95.0 / 5.0)$ \\
\hline Obesity = no/yes $(\%)$ & $40 / 20(66.7 / 33.3)$ \\
\hline DVT $=$ no/yes $(\%)$ & $57 / 3(95.0 / 5.0)$ \\
\hline \multicolumn{2}{|l|}{ Examination } \\
\hline $\mathrm{BP}=$ no/yes $(\%)$ & $37 / 23(61.7 / 38.3)$ \\
\hline Edema $=$ no/yes $(\%)$ & $4 / 56(6.7 / 93.3)$ \\
\hline lymphatics = no/yes $(\%)$ & $30 / 30(50.0 / 50.0)$ \\
\hline BMI (median [IQR]) & $25.00[24.00,30.00]$ \\
\hline Varicose vein $=$ no/yes $(\%)$ & $58 / 2(96.7 / 3.3)$ \\
\hline Peripheral pulses $=$ no/yes $(\%)$ & $15 / 45(25.0 / 75.0)$ \\
\hline
\end{tabular}

All these patients with cellulitis had microbiologically positive infections. The most common organism associated with cellulitis in our study was streptococci. Streptococci were positive in $28(46.7 \%)$ patients. Table 2 shows the microbiological profile of the study population. Culture and sensitivity of the microbiological flora isolated from the cellulitis is shown in table 3 .

Table 2: Microbiological profile

\begin{tabular}{|l|c|}
\hline Variable & [ALL] N=60 \\
\hline Microbiology: & \\
\hline Klebsiella & $6(10.0 \%)$ \\
\hline Mixed growth & $5(8.33 \%)$ \\
\hline Pseudomonas & $13(21.7 \%)$ \\
\hline Staphylococcus & $6(10.0 \%)$ \\
\hline Sterile & $2(3.33 \%)$ \\
\hline Streptococci & $28(46.7 \%)$ \\
\hline
\end{tabular}

Table 3: Antibiotic sensitivity

\begin{tabular}{|c|c|c|c|c|}
\hline & 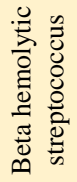 & 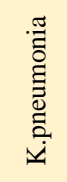 & 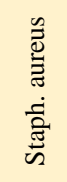 & 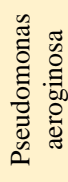 \\
\hline Penicillin & 80.3 & - & 82.3 & - \\
\hline Amoxyclav & 86.4 & 20.8 & 92.8 & - \\
\hline Oxacillin & 74.0 & - & 40.7 & - \\
\hline Piperacillin TZ & 100 & 100 & 100 & 100 \\
\hline Ceftazidime & - & 35.8 & - & 93.5 \\
\hline Cefaperazone SB & 85.1 & 100 & 87.1 & 90.3 \\
\hline Ciprofloxacin & - & 58.1 & 66.6 & 61.2 \\
\hline Gentamicin & & - & 54.1 & 32.2 \\
\hline Amikacin & - & 68.5 & - & 77.4 \\
\hline Cefuroxime & - & - & 77.7 & - \\
\hline Erythromycin & 78.3 & - & - & - \\
\hline Imipenam & 100 & 100 & 100 & 100 \\
\hline
\end{tabular}

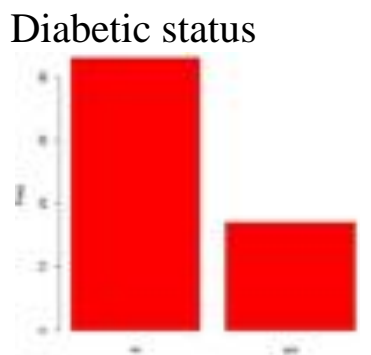

Alcoholism

Edema

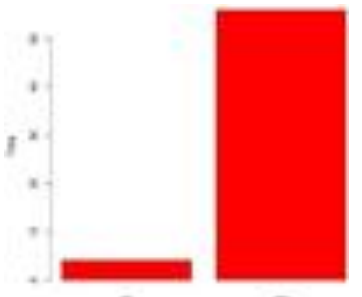

Smoking

Figure: 1 Predisposing factors

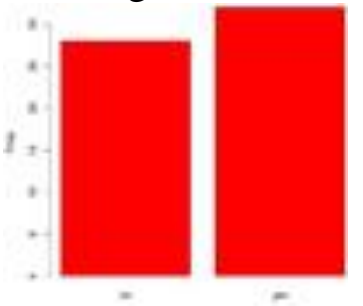

$=$

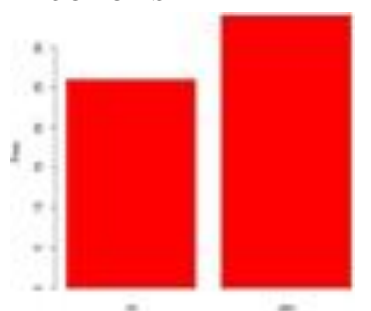

$=$

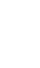
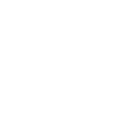
Table 4: Overall analysis

\begin{tabular}{|c|c|c|c|c|c|c|}
\hline Variable & $\begin{array}{c}{[\mathrm{ALL}]} \\
\mathrm{N}=60\end{array}$ & $1 \mathrm{~N}=7$ & $2 \mathrm{~N}=35$ & $3 \mathrm{~N}=8$ & $4 \mathrm{~N}=10$ & $\begin{array}{c}\text { p. } \\
\text { overall }\end{array}$ \\
\hline Age & $\begin{array}{c}54.4 \\
(11.9) \\
\end{array}$ & $\begin{array}{c}50.7 \\
(17.9) \\
\end{array}$ & $\begin{array}{c}54.7 \\
(10.1) \\
\end{array}$ & $\begin{array}{c}54.4 \\
(16.0) \\
\end{array}$ & \begin{tabular}{|c|}
56. \\
$1(10.3)$ \\
\end{tabular} & 0.833 \\
\hline Sex: & & & & & & 0.069 \\
\hline Female & $\begin{array}{c}13 \\
(21.7 \%)\end{array}$ & $\begin{array}{c}1 \\
(14.3 \%)\end{array}$ & $\begin{array}{c}8 \\
(22.9 \%)\end{array}$ & $\begin{array}{c}4 \\
(50.0 \%)\end{array}$ & $\begin{array}{c}0 \\
(0.00 \%)\end{array}$ & \\
\hline Male & $\begin{array}{c}47 \\
(78.3 \%)\end{array}$ & $\begin{array}{c}6 \\
(85.7 \%)\end{array}$ & $\begin{array}{c}27 \\
(77.1 \%)\end{array}$ & $\begin{array}{c}4 \\
(50.0 \%)\end{array}$ & $\begin{array}{c}10 \\
(100 \%)\end{array}$ & \\
\hline $\begin{array}{l}\text { Duration. } \\
\text { days. }\end{array}$ & $\begin{array}{c}6.77 \\
(3.04)\end{array}$ & $\begin{array}{c}6.86 \\
(4.26)\end{array}$ & $\begin{array}{c}7.06 \\
(2.67) \\
\end{array}$ & \begin{tabular}{|c|}
6.12 \\
$(3.14)$ \\
\end{tabular} & $\begin{array}{c}6.20 \\
(3.61) \\
\end{array}$ & 0.803 \\
\hline H/O trauma: & & & & & & 0.003 \\
\hline no & $\begin{array}{c}47 \\
(78.3 \%)\end{array}$ & $\begin{array}{c}2 \\
(28.6 \%)\end{array}$ & $\begin{array}{c}31 \\
(88.6 \%)\end{array}$ & $\begin{array}{c}5 \\
(62.5 \%)\end{array}$ & $\begin{array}{c}9 \\
(90.0 \%)\end{array}$ & \\
\hline yes & $13(21.7 \%)$ & $\begin{array}{c}5 \\
(71.4 \%)\end{array}$ & $\begin{array}{c}4 \\
(11.4 \%) \\
\end{array}$ & \begin{tabular}{c|}
3 \\
$(37.5 \%)$ \\
\end{tabular} & $\begin{array}{c}1 \\
(10.0 \%) \\
\end{array}$ & \\
\hline H/O lymphedema: & & & & & & 0.664 \\
\hline no & $\begin{array}{c}58 \\
(96.7 \%)\end{array}$ & $\begin{array}{c}7 \\
(100 \%)\end{array}$ & $\begin{array}{c}34 \\
(97.1 \%)\end{array}$ & $\begin{array}{c}8 \\
(100 \%)\end{array}$ & $\begin{array}{c}9 \\
(90.0 \%)\end{array}$ & \\
\hline yes & $\begin{array}{c}2 \\
(3.33 \%)\end{array}$ & $\begin{array}{c}0 \\
(0.00 \%)\end{array}$ & $\begin{array}{c}1 \\
(2.86 \%)\end{array}$ & $\begin{array}{c}0 \\
(0.00 \%)\end{array}$ & $\begin{array}{c}1 \\
(10.0 \%)\end{array}$ & \\
\hline H/O.DM: & & & & & & 0.001 \\
\hline no & $\begin{array}{c}23 \\
(38.3 \%)\end{array}$ & $\begin{array}{c}7 \\
(100 \%)\end{array}$ & $\begin{array}{c}8 \\
(22.9 \%)\end{array}$ & $\begin{array}{c}3 \\
(37.5 \%) \\
\end{array}$ & $\begin{array}{c}5 \\
(50.0 \%)\end{array}$ & \\
\hline yes & $\begin{array}{c}37 \\
(61.7 \%) \\
\end{array}$ & $\begin{array}{c}0 \\
(0.00 \%) \\
\end{array}$ & $\begin{array}{c}27 \\
(77.1 \%) \\
\end{array}$ & $\begin{array}{c}5 \\
(62.5 \%) \\
\end{array}$ & $\begin{array}{c}5 \\
(50.0 \%) \\
\end{array}$ & \\
\hline H/O smoking: & & & & & & 0.257 \\
\hline no & $\begin{array}{c}28 \\
(46.7 \%)\end{array}$ & $\begin{array}{c}4 \\
(57.1 \%)\end{array}$ & $\begin{array}{c}17 \\
(48.6 \%)\end{array}$ & $\begin{array}{c}5 \\
(62.5 \%) \\
\end{array}$ & $\begin{array}{c}2 \\
(20.0 \%)\end{array}$ & \\
\hline yes & $\begin{array}{c}32 \\
(53.3 \%) \\
\end{array}$ & $\begin{array}{c}3 \\
(42.9 \%) \\
\end{array}$ & $\begin{array}{c}18 \\
(51.4 \%) \\
\end{array}$ & \begin{tabular}{|c|}
3 \\
$(37.5 \%)$ \\
\end{tabular} & $\begin{array}{c}8 \\
(80.0 \%) \\
\end{array}$ & \\
\hline H/O alcoholism: & & & & & & 0.283 \\
\hline no & $\begin{array}{c}26 \\
(43.3 \%)\end{array}$ & $\begin{array}{c}4 \\
(57.1 \%) \\
\end{array}$ & $\begin{array}{c}15 \\
(42.9 \%)\end{array}$ & $\begin{array}{c}5 \\
(62.5 \%) \\
\end{array}$ & $\begin{array}{c}2 \\
(20.0 \%) \\
\end{array}$ & \\
\hline yes & $\begin{array}{c}34 \\
(56.7 \%)\end{array}$ & $\begin{array}{c}3 \\
(42.9 \%) \\
\end{array}$ & $\begin{array}{c}20 \\
(57.1 \%) \\
\end{array}$ & $\begin{array}{c}3 \\
(37.5 \%) \\
\end{array}$ & $\begin{array}{c}8 \\
(80.0 \%) \\
\end{array}$ & \\
\hline Microbiology: & & & & & & 0.572 \\
\hline Klebsiella & $\begin{array}{c}6 \\
(10.0 \%)\end{array}$ & $\begin{array}{c}0 \\
(0.00 \%)\end{array}$ & $\begin{array}{c}5 \\
(14.3 \%)\end{array}$ & $\begin{array}{c}1 \\
(12.5 \%)\end{array}$ & $\begin{array}{c}0 \\
(0.00 \%)\end{array}$ & \\
\hline Mixed growth & $\begin{array}{c}5 \\
(8.33 \%)\end{array}$ & $\begin{array}{c}0 \\
(0.00 \%)\end{array}$ & $\begin{array}{c}3 \\
(8.57 \%)\end{array}$ & $\begin{array}{c}1 \\
(12.5 \%)\end{array}$ & $\begin{array}{c}1 \\
(10.0 \%)\end{array}$ & \\
\hline Pseudomonas & $\begin{array}{c}13 \\
(21.7 \%)\end{array}$ & $\begin{array}{c}1 \\
(14.3 \%) \\
\end{array}$ & $\begin{array}{c}5 \\
(14.3 \%) \\
\end{array}$ & $\begin{array}{c}2 \\
(25.0 \%) \\
\end{array}$ & $\begin{array}{c}5 \\
(50.0 \%) \\
\end{array}$ & \\
\hline Staphylo-coccus & $\begin{array}{c}6 \\
(10.0 \%)\end{array}$ & $\begin{array}{c}1 \\
(14.3 \%) \\
\end{array}$ & $\begin{array}{c}5 \\
(14.3 \%) \\
\end{array}$ & \begin{tabular}{c|}
0 \\
$(0.00 \%)$ \\
\end{tabular} & $\begin{array}{c}0 \\
(0.00 \%) \\
\end{array}$ & \\
\hline Sterile & $\begin{array}{c}2 \\
(3.33 \%)\end{array}$ & $\begin{array}{c}0 \\
(0.00 \%)\end{array}$ & $\begin{array}{c}1 \\
(2.86 \%)\end{array}$ & \begin{tabular}{c|}
0 \\
$(0.00 \%)$ \\
\end{tabular} & $\begin{array}{c}1 \\
(10.0 \%) \\
\end{array}$ & \\
\hline Streptococci & $\begin{array}{c}28 \\
(46.7 \%) \\
\end{array}$ & $\begin{array}{c}5 \\
(71.4 \%) \\
\end{array}$ & $\begin{array}{c}16 \\
(45.7 \%) \\
\end{array}$ & \begin{tabular}{c|}
4 \\
$(50.0 \%)$ \\
\end{tabular} & $\begin{array}{c}3 \\
(30.0 \%) \\
\end{array}$ & \\
\hline Diabetic status: & & & & & & 0.002 \\
\hline no & $\begin{array}{c}43 \\
(71.7 \%) \\
\end{array}$ & $\begin{array}{c}1 \\
(14.3 \%)\end{array}$ & $\begin{array}{c}30 \\
(85.7 \%) \\
\end{array}$ & \begin{tabular}{|c|}
5 \\
$(62.5 \%)$ \\
\end{tabular} & $\begin{array}{c}7 \\
(70.0 \%) \\
\end{array}$ & \\
\hline yes & $\begin{array}{c}17 \\
(28.3 \%)\end{array}$ & $\begin{array}{c}6 \\
(85.7 \%)\end{array}$ & $\begin{array}{c}5 \\
(14.3 \%)\end{array}$ & $\begin{array}{c}3 \\
(37.5 \%) \\
\end{array}$ & $\begin{array}{c}3 \\
(30.0 \%)\end{array}$ & \\
\hline
\end{tabular}

\section{Discussion}

The study was conducted under the Department of Surgery, Government Medical College Trivandrum. Our intention was to find out the microbiological spectrum and culture sensitivity in cellulites of lower limb. Based on the clinical features, routine blood investigations, culture from infected skin and subcutaneous tissue, a total of 60 patients were studied and the diagnosis of cellulitis was made ${ }^{(13)}$.
In our study the estimated bacteriological spectrum and culture reviled $33.3 \%$ of beta haemolytic streptococci, $8.3 \%$ of staphylococcus aureus, $6.6 \%$ klebsiella pneumonia, 5\% pseudomonas aeruginosa and $10 \%$ mixed growth. ${ }^{(14)}$.

Gram positive organisms mainly beta haemolytic streptococci were the predominantly seen type in our study. This was in concordance with the findings of Erikson $\mathrm{B}$ et al in which beta haemolytic streptococci were detected in $34 \%$ of the patients. ${ }^{(15,16)}$ Fifty patients with cellulitis were prospectively evaluated by Edward W Hook III et al and made similar conclusions (17). Beta haemolytic streptococci were isolated from 17 primary lesions and coagulase positive staphylococci from 13 primary lesions.

With respect to the antibiotic sensitivity, most of the beta haemolytic streptococci were sensitive to pencillins and erythromycin and most of staphylococci species were sensitive to pencillin and pipperacillin tazobactam combination. ${ }^{(18)}$ Regarding gram negative organisms pseudomonas and klebsiella species were sensitive to Imipenam, aminoglycosides, and pipperacillin tazobactam ${ }^{(19)}$. In concordance with our study the results obtained by Siggurdsson et al showed that all staphylococcus aureus and beta haemolytic streptococci were sensitive to pencillins. The etiology of bacterial cellulitis was determined by fine-needle aspiration. But contradicting to our study the most common bacteria isolated was staphylococcus aureus.

Lymphedema, obesity, venous insufficiency, and dermatological diseases were shown to be independently related to cellulitis of lower extremity by Dupuy A et al in their study ${ }^{(20)}$. Among 60 patients in the present study, $76 \%$ were overweight, $21.6 \%$ were with varicose veins, $61.7 \%$ patient were associated with diabetes mellitus, $21.3 \%$ had previous history of trauma and $3.3 \%$ had lymphedema. A larger study will be needed to assess the risk factors of lower limb cellulitis.

In the present study the most common gram positive organism isolated was beta haemolytic 
streptococci and klebsiella species among the gram negative group. The main associating factors which could be identified include certain factors like overweight, obesity, diabetes mellitus, previous history of trauma and varicose veins.

\section{Acknowledgement}

We would like to thank Dr. I.P. Yadev for his help in analyzing the data and his constant inspiration all throughout the study period.

\section{Reference}

1. Swartz MN. Cellulitis. New England Journal of Medicine. 2004;350(9):904-12.

2. Bisno AL, Stevens DL. Streptococcal Infections of Skin and Soft Tissues. New England Journal of Medicine. 1996;334 (4):240-6.

3. Baddour LM. Cellulitis syndromes: an update. International journal of antimicrobial agents. 2000;14(2):113-6.

4. Nichols RL, Florman S. Clinical presentations of soft-tissue infections and surgical site infections. Oxford University Press; 2001.

5. Rendi-Wagner P, Schwartz E. Epidemiology of Post-Travel Illnesses. Tropical Diseases in Travelers. 2009:13-26.

6. Claeys KC, Lagnf AM, Patel TB, Jacob MG, Davis SL, Rybak MJ. Acute Bacterial Skin and Skin Structure Infections Treated with Intravenous Antibiotics in the Emergency Department or Observational Unit: Experience at the Detroit Medical Center. Infectious Diseases and Therapy. 2015;4(2):173-86.

7. Chlebicki MP, Oh CC. Recurrent cellulitis: risk factors, etiology, pathogenesis and treatment. Current infectious disease reports.2014;16(9):1-8.

8. Ki V, Rotstein C. Bacterial skin and soft tissue infections in adults: A review of their epidemiology, pathogenesis, diagnosis, treatment and site of care. The Canadian
Journal of Infectious Diseases \& Medical Microbiology. 2008;19(2):173-84.

9. Tiwari AK, Lal R. Study to evaluate the role of severity stratification of skin and soft tissue infections (SSTIs) in formulating treatment strategies and predicting poor prognostic factors. International journal of surgery.12(2):125-33.

10. Misiakos EP, Bagias G, Patapis P, Sotiropoulos D, Kanavidis P, Machairas A. Current Concepts in the Management of Necrotizing Fasciitis. Frontiers in Surgery. 2014;1:36.

11. Roje Z, Roje Ž, Matić D, Librenjak D, Dokuzović S, Varvodić J. Necrotizing fasciitis: literature review of contemporary strategies for diagnosing and management with three case reports: torso, abdominal wall, upper and lower limbs. World journal of emergency surgery : WJES. 2011;6:46.

12. Kilburn SA, Featherstone P, Higgins B, Brindle R. Interventions for cellulitis and erysipelas. Cochrane Database of Systematic Reviews. 2010(6).

13. Duvanel T, Auckenthaler R, Rohner P, Harms M, Saurat JH. Quantitative cultures of biopsy specimens from cutaneous cellulitis. Arch Intern Med. 1989;149 (2):293-6.

14. Eriksson B, Jorup-Ronstrom C, Karkkonen K, Sjoblom AC, Holm SE. Erysipelas: clinical and bacteriologic spectrum and serological aspects. Clinical infectious diseases: an official publication of the Infectious Diseases Society of America. 1996;23(5):1091-8.

15. Hederstedt B, Holm SE, Norberg R. Extremely high titers of serum antibodies against the streptococcal exoenzyme deoxyribonuclease B. Journal of clinical microbiology. 1980;11(6):720-3.

16. Leppard BJ, Seal DV, Colman G, Hallas G. The value of bacteriology and serology in the diagnosis of cellulitis and erysipelas. 
The British journal of dermatology. 1985;112(5):559-67.

17. Hook EW, 3rd, Hooton TM, Horton CA, Coyle MB, Ramsey PG, Turck M. Microbiologic evaluation of cutaneous cellulitis in adults. Arch Intern Med. 1986;146(2):295-7.

18. Jorup-Ronstrom C, Britton S, Gavlevik A, Gunnarsson K, Redman AC. The course, costs and complications of oral versus intravenous penicillin therapy of erysipelas. Infection. 1984;12(6):390-4.

19. Dall L, Peterson S, Simmons T, Dall A. Rapid resolution of cellulitis in patients managed with combination antibiotic and anti-inflammatory therapy. Cutis. 2005;75(3):177-80.

20. Dupuy A, Benchikhi H, Roujeau JC, Bernard P, Vaillant L, Chosidow O, et al. Risk factors for erysipelas of the leg (cellulitis): case-control study. Bmj. 1999;318(7198):1591-4. 